\title{
Housing provision in 21st century Europe
}

\author{
Article
}

Accepted Version

Creative Commons: Attribution-Noncommercial-No Derivative Works 4.0

Ball, M. (2016) Housing provision in 21st century Europe. Habitat International, 54 (3). pp. 182-188. ISSN 0197-3975 doi: https://doi.org/10.1016/j.habitatint.2015.11.024 Available at https://centaur.reading.ac.uk/60426/

It is advisable to refer to the publisher's version if you intend to cite from the work. See Guidance on citing.

To link to this article DOI: http://dx.doi.org/10.1016/j.habitatint.2015.11.024

Publisher: Elsevier

All outputs in CentAUR are protected by Intellectual Property Rights law, including copyright law. Copyright and IPR is retained by the creators or other copyright holders. Terms and conditions for use of this material are defined in the End User Agreement.

\section{www.reading.ac.uk/centaur}

\section{CentAUR}

Central Archive at the University of Reading

Reading's research outputs online 


\title{
Housing provision in $21^{\text {st }}$ century Europe
}

\author{
Michael Ball*
}

\begin{abstract}
European housing markets exhibited considerable volatility so far in the $21^{\text {st }}$ century while affordability worsened for many. Boom-bust has had greater housing impacts than any specific housing policy, which illustrates the difficulty in policy terms of seeing housing in isolation and the central significance of interlinked relationships between housing, the economy and financial markets. Europe historically invented a powerful set of interventionist tools to alter housing circumstances but, as the overview of rental markets here indicates, today they have mixed success. Examples of what to avoid in policy are at least as common as exemplars.
\end{abstract}

Key words: housing provision, housing policy, affordability, financial markets

\section{Introduction}

Crisis and affordability are central themes here, because so far in the 21st century they have dominated European housing provision. Experience has been varied but central are events surrounding the Global Financial Crisis (GFC) and the travails of the Eurozone and policy reactions to both. Therefore, no examination of housing policy can ignore them. Weaved into the narrative is an analysis of some key structural policy issues as they help to explain why some European countries were particularly badly affected while others were not. Affordability has been a growing problem, partly because the booms priced out many while the aftermath saw plummeting housebuilding and credit availability.

Variety is another theme as Europe's 900 million people live in a large number of countries. There are nearly 20 with populations of 9 million or more, plus another 28 smaller ones. So, inevitably there are diverse housing experiences, institional frameworks and policies. A long tradition of activist housing policy also exists. So,

\footnotetext{
*Professor, University of Reading, UK. Email: m.ball@reading.ac.uk
} 
one unifying characteristic is political rhetoric, which generally projects notions of effective and fair micromanagement though the evidence is mixed to say the least.

Though conditions and costs do vary widely, it remains the case that in aggregate Europe is relatively well housed in contrast to the past. Yet, paradoxically, dissatisfaction with housing provision is currently pervasive. On the upside, most people can find decent (if not ideal) accommodation with their means (if only just) in (tolerably) convenient places. On the downside, policy makers almost everywhere are pondering how improve affordability and whether more or less intervention is the way forward.

Subsequent sections can only cover a small amount of the potential issues that could be discussed and. After identifying what makes Europe special and noting four key characteristics that need to be borne in mind in policy debate, the impact of the 2000s boom-bust cycle is examined. Following this, there is consideration of one of the prime features that distinguish European housing policy, that with regard to rental housing.

\section{Europe as a special case}

Europe has a rich history of housing policy that has often be used as templates elsewhere. This is especially true of those countries with a strong state-led social welfare tradition. Observers identify this as something that makes Europe special: with a divergence from, for example, the USA in welfare interventions from the 1920s onwards (Alesina et al, 2001). They put this down to initial conditions arising from the major transformations of Europe as a consequence of inter-war depression and the two world wars themselves. Social and political upheavals weakened tradition elites, strengthened strong reformist movements and forged a myriad of countries that, at least for a time, had relative social homogeneity. In combination, these features help to nurture policies of state-led mutual support with political parties having to put social wellbeing at the centre of their programmes. A strongly interventionist role for the state was set in motion that continues today nationally and in the super-national European Union.

Post-war rapid economic growth made welfare policies feasible and they become firmly entrenched by the last quarter of the twentieth century. Housing policy was a key element in this state welfare/mixed economy framework. In varying ways, both owner occupation and rental housing were supported through demand and supplyside programmes. However, more recently the old parameters have been breaking 
down (Hamerijck, 2012; Chatham House, 2015) and there has been considerable policy change amidst broad institutional continuity.

Those traditions were most successfully imbedded in North Western Europe Benelux, France, Germany, the Nordic countries and the UK. By contrast, Central and Eastern European (CEE) countries have over the past quarter of century been refashioning market-based economies from a post-war 'state socialism' legacy, while Southern ones have each had further distinct 'take-off' trajectories. Yet, they all have lower levels of formal social provision and stronger traditions of family supports, including with respect to housing (Morris et al, 2014). Housing standards are generally substantially lower, in CEE especially, and there are typically high levels of owner occupation.

\section{Four important features of European housing}

Europe exemplifies a number of key features of contemporary housing provision that it is useful to identify.

\section{Institutional distinctiveness}

Its countries each contain their own unique set of housing institutions and policies. They highlight that housing markets remain national and local in character. Even with globalised finance, distinctive characteristics of mortgage markets abound. Understanding may involve intellectual tools that transcend national boundaries but outcomes are filtered through specific institutions and political processes (Ball, 2006). So, it is difficult to read off policy conclusions from simple comparisons. Space does not enable detailed evaluation of the impact of these distinct European structures of housing provision but their existence is implicit in what follows.

\section{Scarcity amidst plenty}

Though basic needs of shelter and health are generally met, housing shortages abound. A prime cause is the desire to crowd into a small part of the available land, especially into booming regions. For example, in England only $6 \%$ of all land is in residential use and new housing takes up far less (DCLG, 2015). Therefore, scarcity is to a considerable degree socially created, with location having pre-eminence over housing affordability and quality. Inequality is exacerbated by competition for this prized urban space.

\section{Regulation and path dependency}


European housing is highly regulated with myriad rules and organisations that have evolved topsy-turvy over time and been influenced by the ebbs-and-flows of political fashion and path dependency. It is unlikely that anyone would design what exists in its entirety from scratch. However, reform has to start from what exists and so inevitably tends to meet resistance and tends to be slow and path dependent.

\section{Cyclical variability}

Housing markets are characterised by cycles. European countries, as elsewhere, have experienced many phases of boom and bust in their housing histories. Moreover, looking at the very long-run it is clear that these cycles are relatively weakly correlated across countries in timing and amplitude (Barras, 2008; Ball and Morrison, 2000), though the Global Financial Crisis (GFC) proved a common turning point in many countries, but not all.

\section{The Great $21^{\text {st }}$ Century Boom And Bust}

\section{i) The boom}

The great house European house price boom was unprecedented. By 2007, real house prices had at least doubled over the past decade in the Nordic region, Benelux, France, the UK, Ireland and Spain. Shorter booms occurred in new build markets in Central and Eastern Europe. By contrast, there were only modest price rises in Italy and real falls in Germany, Austria and Switzerland, partly because their housing market cycles were and remain distinctive. A combination of events put so many European countries at the forefront of the global house price excesses of the 2000s. They are briefly considered below.

Optimism was fed by the length of time of the rise in prices. Economies were strong and the scourges of high inflation and instability seemed to be finally beaten. Nominal interest rates had been falling for a long period of time and credit conditions were becoming looser. Both consumers and lenders fooled themselves into believing that a new era had dawned, which helped to stoke up expectations of ever-rising house prices.

Change was also taking place in mortgage market structures. Residential mortgage backed securities, which hardly existed in Europe at the turn of the century, provided substantial new sources of funds; especially in the UK, Spain and the Netherlands. They facilitated the entry of new lenders. Incumbents then retaliated against falling market shares by relaxing their own lending criteria. Elsewhere, previously sedate mortgage markets, such as Denmark's, saw lender competition escalate via new, 
higher risk products. The outcome was that outstanding mortgage debt to GDP levels rose strongly in the UK, Denmark, Ireland, Spain and the Netherlands: though not in others, such as Sweden and Norway, where mortgage market structures changed little.

The introduction of the Euro added further stimulus to household debt. It brought lending rates down sharply in southern Europe and added to consumer euphoria, particularly in Ireland, Spain, Portugal and Greece.

It would be wrong to see the Europe's 2000s boom simply as a credit bubble. Underlying structural conditions contributed much. For example, favourable tax breaks for owner-occupiers and generally low property taxes added to the fuel. Not all countries offered mortgage interest tax deductibility for owner-occupiers but those that did saw some of the highest price increases.

Housing demand was spatially concentrated into areas where supply was shortest. Demographics and migration added to accelerating market momentum. Net migration grew particularly after expansion of the European Union into Central and Eastern Europe, putting further pressure on local housing markets in the net recipient areas. However, such housing costs are associated with positive aggregate contributions to economic growth and public finances, which could be argued to more than counter-balance them (Peri, 2013; Dustmann and Fratinni, 2014). The net flow of migrants (internal as well as foreign) was concentrated into capital cities and, at the European level, across southern France, northern Italy, the Benelux countries and much of the United Kingdom (Eurostat, 2014a).

Supply-side conditions contributed much. With a few exceptions, rental-housing supply was stagnant or declining, with investment discouraged by rent controls, and thus failed to absorb demand increases (Scanlon and Elsinga, 2013). This pushed more towards either house purchase or poor quality living.

Neglect of infrastructure investment frustrated urban expansion. In the UK, the Netherlands and Sweden, housebuilding hardly responded to increases in demand and that helped to push up prices over a long period of time (Barker, 2004; Ball, 2012). Elsewhere, even if supply eventually came on stream, it could be poorly located and badly built; as, for example, in Ireland and Spain where homebuilding reached unsustainable levels that intensified and prolonged subsequent crashes (Norris and Coates, 2014). Credit booms also weakened risk assessments of developer loans, so many high risk projects were unwisely funded. 
Planning and building controls remained slow and cumbersome throughout the continent, raising the costs and uncertainties surrounding housebuilding projects (Ball, 2010; Andrews et al., 2011). Thus, poor local authority incentives were causes of both a lack of building land and sluggish supply responses.

ii) The bust

The downswing in Europe lagged that in the USA's by around a year. The gradual decline spread across Europe and became a generalised crisis in 2008. Banks with high exposure to mortgage and developer lending and to RMBS were particularly affected, with failures or bailouts in Ireland, UK, Germany, Spain, Austria and the Netherlands.

Mortgage debt was concentrated in the hands of a minority of households but, in aggregate, still represented high levels relative to GDP (Table 1). Such highly indebted consumers reduced general consumption helping to push those economies that had had the greatest debt fuelled booms into recession (Mian \& Sufi, 2014; Summers, 2014). Yet there was no simple correlation between the degree of indebtedness and the subsequent collapse in house prices, but the bust was worst in places where lenders and economies as a whole were most vulnerable.

The sovereign debt crisis in the Eurozone added to market woes in southern Europe. In CEE, there was a mixed response with dramatic collapses in the Baltic States, sharp declines in Slovenia, Romania and Bulgaria and more modest but still severe downswings elsewhere.

The downturn has been prolonged in many countries, with prices falling in some cases for seven years up to the date of writing. This persistence of decline shows the scale of the crash but also the significance of the joint effect of the financial and Eurozone sovereign debt crises. However, some countries, including the Baltic states and Iceland, recovered quickly after severe collapses and failures; provoking debate about whether intervention prolongs rather than alleviates the agony of crisis (Thorhallsson and Kirby, 2011).

A far wider group of countries exhibit persistence when measured in terms of market turnover or housebuilding. EU28 permits data, a leading indicator of future housing output, remained a third of its 2006 peak in 2014 (Eurostat, 2015). Unsurprisingly, decline was greatest in the countries worst affected by the downturn.

The scale of the downswing can be seen in the extent of real house falls across a range of countries between 2007 and 2013, by when recovery had commenced in 
most places, though not in Cyprus, Greece, Italy and Slovenia. Badly hit were Ireland $(-47 \%)$, Spain $(-43 \%)$, and Greece $(-40 \%)$; followed by the Netherlands $(-28 \%)$, Italy $(-20 \%)$ and the UK $(-14 \%)$; with so what less in France $(-8 \%)$. Overall, average EU prices fell by around $14 \%$ similar to those in the USA and around the conventional $14 \%$ benchmark for a real house price bust (IMF, 2002; BIS, 2015).

Table 1: Mortgage debt in selected European countries

Outstanding residential loans to GDP ratios

\begin{tabular}{|l|ccc|c|c|}
\hline \multicolumn{1}{|c}{} & $\mathbf{2 0 0 2}$ & $\mathbf{2 0 0 7}$ & $\mathbf{2 0 1 3}$ & $\mathbf{2 0 0 7}$ & $\begin{array}{c}\text { Change } \\
\text { Ireland }\end{array}$ \\
\cline { 2 - 6 } \\
Germany & 36.1 & 74.1 & 57.8 & 38 & -16.3 \\
Spain & 53.5 & 47.6 & 44.2 & -5.9 & -3.4 \\
UK & 35.9 & 61.4 & 59.9 & 25.5 & -1.5 \\
Italy & 60.4 & 77.6 & 80.6 & 17.2 & 3 \\
Denmark & 11.5 & 17.1 & 23.2 & 5.6 & 6.1 \\
Netherlands & 59.4 & 85.8 & 93.8 & 26.4 & 8 \\
France & 80.2 & 96.2 & 104.9 & 16 & 8.7 \\
Belgium & 22.7 & 34.6 & 43.8 & 11.9 & 9.2 \\
Sweden & 27.7 & 37.6 & 49.5 & 9.9 & 11.9 \\
EU28 & 50 & 64.5 & 80.9 & 14.5 & 16.4 \\
USA & 37.1 & 48.1 & 51.1 & 11 & 3 \\
\hline
\end{tabular}

Source: European Mortgage Federation. Note: Cross-country comparison is imperfect because residential debt is not only held by private individuals but not all non-household residential debt is recorded here; furthermore, the table includes only debt secured on mortgages.

Not all countries fared badly. In Germany, Austria and Switzerland house prices rose rapidly after 2008 ending long periods of market weakness. Whereas in Norway and Sweden prices continued to boom, after a brief blip, with higher housebuilding and mortgage levels. Credit availability remained good and cuts in interest rates stimulated demand. Public deficits were limited and few mortgage institutions were affected by the GFC.

Many CEE borrowers had taken out foreign currency loans, especially in Swiss Francs, misguidedly discounting the foreign exchange rate risk in order to benefit from lower interest rates. As exchange rates turned severely against them, repayment profiles rocketed. Policy debate since then in these countries has centred on restricting 
future foreign currency loans and identifying the extent to which mis-selling by mainly foreign bank lenders was to blame. Hungary has had the most aggressive stance; including introducing programmes to convert loans previously denominated in foreign currency to the national one at exchange rates highly favourable to borrowers, with lenders bearing the loss. However, such an approach discourages further lending activity in what are still nascent mortgage markets, where competition and knowledge transfer from foreign banks remain crucial.

\section{Policy responses to the crisis}

\section{Monetary Policy}

Monetary policy was not specifically directed at housing. Nonetheless, the European (and other) Central Bank's interest rate and quantitative easing policies had a considerable effect. The impact of monetary policy gradually reversed falling housing demand through its economic stimulus, improved mortgage availability and cheaper borrowing costs. Lower interest rates had the added advantage that they made existing mortgage repayments more affordable in countries where variable mortgage interest rates were significant. This limited non-performing loans and repossessions. The UK where housing loans have variable or limited fixed rates, for example, had surprisingly few, despite the scale of personal indebtedness. An unexpectedly small rise in unemployment during the recession helped, as a loss of jobs was a significant contributory factor in high arrears countries.

In the worst affected countries mortgage arrears were significant. Non-performing loans to Spanish households remain high at 13\% of loans (Bank of Spain, 2015). There was a similar story in Ireland. Mortgages arrears (90 days + ) peaked at $13 \%$ of all mortgages in 2013. However, repossessions remained low throughout the crisis years, in contrast to the USA and Spain, as the government and monetary authorities adopted policies to keep households narrowly afloat. Forbearance techniques in Ireland contained a variety of approaches: switching to an interest-only mortgage, payment amount reduction, deferral, extension of loan term and capitalising arrears (CBol, 2015; Andritzky, 2014).

After the surge in household borrowing in the run up to the GFC, deleveraging was inevitable and desirable. Without it, a quick recovery and sustained general economic expansion are less likely (Chen et al., 2015; Summers, 2014; Mian and Sufi, 2014). Some did occur in Europe, such as in Ireland and the UK, but not on the scale of the USA. Consumers in quite a number of European countries remain heavily 
indebted (IMF, 2014). This has helped to contribute to the slowness of the recovery in much of Europe and adds risks for the future.

Monetary policy mistakes were clearly made. For example, the Bank of England was initially slow to respond to the collapse of mortgage lender Northern Rock in 2007. Sweden sharply raised interest rates in 2010 to dampen escalating house prices and high household debt (170\% of GDP in 2014) despite low inflation. But the cost proved high for the economy in general, so four years later rates were lowered to zero (Milne, 2014). This again fuelled debt and house price growth, so that Swedish households are now some of the most globally indebted; highlighting the dilemmas associated with using monetary policy to dampen asset price booms.

\section{Fiscal policies}

Fiscal policies were limited by growing public sector deficits and the Eurozone sovereign debt crisis but, even so, a number of countries adopted them. One route was encouraging social housing institutions to build more, as in France, the Netherlands and the UK (Ball, 2012). However, their impact was modest. Of greater consequence were temporary tax breaks, as in France with additional tax credits to landlords for new homes but this programme was cut in as the country's fiscal problems mounted. In the UK, attempts were made to stimulate first-time buyer demand for new homes with loan guarantee and equity share schemes, associated with $15 \%$ of new build in 2013/14 (Birch, 2014).

Standard criticisms of such fiscal policies are their cost and efficiency; concerns over political manipulation; questions over how much net new demand is actually generated; and fears over the potential for raising house prices. Timing is also an issue as policies take time to have an impact, by when the need for stimulus may have gone.

Fiscal retrenchment forced some reduction in tax breaks though most remain. Two of the few examples occurred with regard to mortgage interest tax relief in Spain and the Netherlands.

\section{The persistence of unaffordability}

In terms of income, for example, a 2010 EU-wide survey found that $34 \%$ of Europeans felt they faced disproportionate housing costs and that the situation had become much worse over the previous five years. For lower income groups, $60 \%$ said they faced such problems (Pittini, 2012). Rents have generally risen faster than incomes since then, so the situation is worsening. By 2012, 11\% of European 
households said that they spent more than $40 \%$ of their disposable income on housing costs, including utilities and repairs; the benchmark used by Eurostat to define housing as unaffordable. At the country level, the situation varied markedly. Around third of Greeks and a fifth of Danes faced affordability problems and around $15 \%$ of households in Germany, the Netherlands, Spain, Romania and Bulgaria while in France only 5\% did (Eurostat, 2014b). By contrast, upward trends in house prices have frequently made post-tax user costs negative for the millions of owners, so housing has become a major influence on growing inequality.

Expensive housing may be but that does not usually seem to lead to extensive overcrowding in Europe. For historic reasons many CEE countries still suffer from high rates of overcrowding with $40 \%$ or more of their households living in poor quality accommodation. However, elsewhere overcrowding is limited to pockets of low-income groups in major cities (Eurostat, 2014b).

There are various causes of the income-related housing affordability problem. The most important centres on the shortage of housing in growth areas, as noted earlier. The collapse in housebuilding in post-2007 crash countries has further contributed to the long-term deterioration in affordability. There are also reduced stocks of below market-rent housing in countries across Europe, a decline that has been going on for sometime (Whitehead and Scanlon, 2007).

Shortages also influence the tenure-choice affordability issue, which relates to the costs of entry to owner occupation. Rising house prices have increased own equity/deposit requirements. This has made it increasingly difficult for younger people to save enough from their incomes while renting to make the transition. Some countries, particularly the UK, have seen declines in home ownership rates in consequence. Significant numbers of British households on around median incomes will now spend much of their lives as renters, with more children growing up in the tenure, in a way that has not happened for over 50 years.

A contributory factor has been the growing ability of existing homeowners to raise their housing consumption and outbid others for the available stock. They particularly benefit from tax breaks and rising housing equity. Greater wealth and attractive loan terms encourage them to consume more housing. Credit rationing rules increasingly give preference to them, while low property taxation discourages downsizing. A classic insider/outsider situation arises. Ageing populations are intensifying the situation, as ownership rates tend to increase with age. This can pass through the generations as older family members remortgage to help younger ones 
buy. A similar beneficial insider effect arises for older incumbents in regulated social and private renting.

Growing income inequality adds further dimensions; because it means that those on median or lower incomes (which includes many of the young as well as the poor) have less relative purchasing power in the competition for scarce land. This may have self-perpetuating consequences, because those unable to find housing in growth areas are less able to participate in labour markets and to raise their human capital by doing so (OECD, 2015).

In many countries, median- to low-income groups fared badly over the last property cycle. They were squeezed out of housing opportunities in the boom years. Then, rising unemployment and weak income growth during the downturn intensified problems and subsequent downward house rent/price adjustment has been insufficient to compensate.

\section{Cyclical and structural influences on markets and policies}

Cyclical activity typically involves interactions between events in housing markets and wider social, economic and financial factors. This was clearly the case with the credit driven booms prior to the GFC. However, finance does not always play the lead role. The innovation of the motorcar and resultant suburbanisation was an innovation stimulus to cycles while the reunification of Germany is a good example of a population driven shock. Furthermore, the industrialisation of emerging economies illustrates drivers of long-cycles stimulated by social innovations, accelerated economic catch up and intense urbanisation. Whatever the initial source, features of the housing markets tend to intensify fluctuations; including supply-side and transactional stickiness, information constraints and an overweighting of recent events in myopic behaviour (e.g. Malpezzi and Whatcher, 2002).

All the available historical evidence suggests that cycles are irregular in the time from peak to peak and vary considerably in amplitude and across markets (Barras, 2009). This often goes unrecognised so that differences in country performance can erroneously be mis-attributed. For example, Germany and Switzerland have had very distinct cyclical patterns over the past three decades compared to say France and the UK. They had falling house prices when others had rising ones up to the mid-2000s. Unsurprisingly, that era for them was conducive to neither increased owner occupation nor post-GFC housing bust. Yet many have erroneously attributed such absences solely to institutional factors and 'better' behaviour (e.g. De Boer and Bitetti, 2014). By contrast, post-2008 has seen renewed interest in ownership on the 
back of rising incomes and cheap mortgages (Wuerst, 2015). Signs of boom times can be seen in price rises in Germany's seven major cities; growing by almost 50\% between 2006 and 2014 (Bundesbank, 2015).

Structural factors - institutional arrangements, including taxes and subsidies; population dynamics; physical geography and the like - are often referred to as 'fundamentals'. Unfortunately, it is not easy to distinguish precisely between them and cycles, especially as structural factors themselves change over time, though plausible approximations are often feasible.

Such ambiguity, of course, is one reason why bubbles may start, because participants may falsely be convinced of fundamental change. A further complicating factor is that cycles themselves generate persistence affects that may alter fundamentals, including policy. An example of this relates to the tightening up loan criteria in the aftermath of the GFC, as the revised rules may permanently alter access to owner occupation but enable easier loans for the equity rich.

\section{Social housing and support for low-income groups}

\section{Social housing}

There is no clear European definition of social housing or its role. Classifications range across providers, subsidies, rent setting and recipients. Sweden and the Netherlands have traditionally had an open-to-all approach and combined it with strict controls in private renting while others target low-income or special needs groups. Subsidy sources vary from direct ones for building, land subventions, nonprofit tax breaks, public and cross-tenant rent subsidies, and loan guarantees. Rent setting policies are also highly varied based on historic loan costs, account balancing or some percentage of market rents (Braga and Palvarini, 2013).

Only a handful of countries have particularly large social housing sectors, illustrating widely different views on its costs and benefits (Whitehead and Scanlon, 2007). The variety partly indicates historical differences, with social housebuilding being particularly fashionable in the decades after the two world wars in several NorthWestern European countries and for some city governments within them.

Social housing has been in numerical decline for several decades, as building has been limited and demolitions and sales frequent. However, in several countries the tenure remains a major provider of homes, particularly of rental properties (Pawson et al., 2011). 
The Netherlands has proportionately the largest sector (over $30 \%$ of all dwellings); in Austria and the UK around a fifth of households live in the tenure; while Denmark, Sweden, Finland and France have shares of 15\% or more (CECODHAS, 2012). Most CEE countries that built up large stocks under communism have sold much off, although Poland (12\%) and other countries still retain publicly-owned, typically very rundown, property (Lux and Sunega, 2014).

Advocates of social housing argue that it is an effective way of ensuring good quality, low-cost housing with benefits in terms of social integration and re-engaging people into work (Frontier Economics, 2014). Others focus on the not-for-profit nature of providers (Rhodes and Mullins, 2009). Suggestions are also made regarding urban regeneration and facilitation of intermediate/hybrid tenures with mixes of owning and renting (Pawson et al., 2011).

Critics argue that social housing is costly and poorly targeted. They also question the evidence on spillover benefits, which tends to be anecdotal and self-referential. Social costs include the risk of negative neighbourhood externalities and the spatial segregation of ethnic minorities and recent migrants into large, malfunctioning estates (Garner and Bhattacharyya, 2011). Evidence indicates higher unemployment rates amongst tenants of working age than is explained by household characteristics alone (Hills, 2007).

Principal-agent problems may arise. Providers operate under near monopoly conditions, strong lobbies and limited scrutiny of their efficiency or probity. This limits incentives to adopt best practice. A recent UK study on cost efficiency, for example, found wide variations between housing associations and no improvement with larger size (HCA, 2012). Scandals led to disenchantment in Germany in the 1980s (Power, 1993) and, recently, in the Netherlands where the largest social housing provider, Vestia, lost over two billion euros on a credit swap deal in 2012. A Parliamentary report on the issue called for the break up of large housing corporations, sales, caps on executive salaries, and increases in rents towards market levels (Allen, 2014; Birch, 2015).

New private building is likely to be crowded out if land supply is constrained. So, the net gain in supply from extra social housebuilding may actually be limited in high demand areas but prices are raised across the private stock. Security of tenure and low rents mean that tenants have no incentives to move or to economise on housing, while subsidises to better-off tenants are regressive. In the more targeted instances, the tenure is inflexible unless tenants can be asked to leave when their circumstances improve. So, the stock has to be larger than those defined as in need. 
Waiting lists are long but that is an almost inevitable situation when rents are set at below market levels. Below market rents also offer incentives for illegal sub-letting at higher ones.

Competition with the private sector has raised issues at the European level because of conflicts with the principle of fair competition when social providers receive subsidies unavailable to others. The European Commission has recently required $90 \%$ of Dutch social housing to be targeted on lower income groups (capped at 33,000 euros pa) in effect abolishing previous policies. This ruling encouraged Belgian developers to press successfully for removal of enforced allocations of development land or its equivalent to social providers. Another case is pending regarding subsidies to social housing in France (UEPC, 2013).

\section{Rent payment support}

Direct, means-tested, rent payment support for both social and private tenants is offered as part of low-income housing policies, though in limited way in most countries. The UK stands out as the exception, where $1.5 \%$ of GDP is spent on 'Housing Benefit', according to 2009 Eurostat data. The current UK government is trying to cap it and to incorporate it into an overall income support. France, Denmark and Germany are the other three EU countries with significant dispensions of 0.6$0.7 \%$ of GDP.

'Rent benefits' cannot sensibly be detached from wider country welfare policies and have been growing as a means of targeting welfare support in a number of European countries (Griggs and Kemp, 2012). They have been supported as a means of sustaining the demand for, and hence the supply of, low-income properties as an alternative to direct supply-side interventions (Turner and Elsinga, 2005). Detailed rules are important for evaluation and impacts are greatest in high-cost areas with low supply elasticities. Broader welfare impacts, like diminishing work incentives, are of concern, as are issues over fairness.

The UK's Housing Benefit covers a third of private and two-thirds of social tenants, with an average of $72 \%$ for private rent levels. This clearly raises demand significantly, particularly in high cost areas where such households would otherwise be squeezed out (Phillips, 2013). They are likely to become capitalised into house prices, diminishing their direct benefit and imposing higher costs on others, who may be entirely crowded out. There is also the issue of location as even within high cost regions rents vary considerably. Social mix is used as a justification for building social 
housing in expensive neighbourhoods, although the benefits are questionable (Cheshire, 2007).

\section{Private Rented Sector}

Rent controls and security of tenure regulations are commonplace across Europe and receive widespread support with claims that they improve fairness and the available housing choice mix; enable long-term tenancies; and help low-income groups (O'Sullivan and De Decker, 2007; Scanlon and Elsinga, 2013; de Boer and Bitetti, 2014). They are usually based on the notions of second-generation rent control (Arnott, 1995). Rents are typically negotiated freely initially (with caveats) but then increases in them are constrained to some external marker, such as the national rent cost index in France.

Security of tenure is paramount when rents fall below market levels; so enforceable contract lengths are stipulated with tenant options for renewal on the same terms across varying degrees of time, depending on the country in question. Courts may create implicit near total security of tenure as they have in Germany. Some countries, such as Sweden and the Netherlands, have strict controls through national or local rent setting, with exceptions for high-end and new build (Ball, 2012).

Only a handful of countries have broadly free rental markets, including the Czech Republic, Finland and the UK. The stock of rental dwellings has been stagnant or falling on a trend basis in most countries but the UK stands out where the tenure has doubled its share since deregulation (Scanlon and Elsinga, 2013).

Discussions about the impact of regulation need to take into account the state of the market. For example, the previously noted long weakness of the German market up to the mid-2000s implies that the rent regulations had little constraining effect in contrast to the situation since then; whereas in countries and cities with significant long-term increases constraints would be binding most of the time.

Evidence in support of regulation is weak. For example, the OECD developed a composite index of rent regulation and found that average rent levels are no lower in more highly regulated countries, possibly because expected increases are frontloaded at the beginning of contracts. Nonetheless, investment and maintenance seemed to be less (Andrews et al., 2011). Rent controls are poorly targeted, often regressive, and favour incumbents over new entrants or those that move frequently (Basu and Emerson, 2000). 
A three-tier rental market emerges. First, existing long-term tenants are the beneficiaries of security and lower rents. Second, relatively affluent, frequent movers appeal to landlords as their behaviour dilutes the impact of controls; while, third, less fortunate new entrants are pushed into the worst parts of the market. The potential for discriminatory outcomes is clearly high and observable.

This tripartite nature of many European private rental markets may help to explain why such policies persist, because the winners are spatially fixed and, so, have more political impact. For example, Germany increased rent control in 2015 following a titfor-tat bidding for votes in the previous general election (Financial Times, 5.3.15).

Elsewhere, economic crisis has forced deregulation with the aim of increasing the role of private renting. This occurred in Spain and the Czech Republic post-2008 and more tentatively in the Netherlands. More generally, taxation on landlords has increased in response to fiscal concerns whereas previously breaks encouraged investment despite market regulation. The threat of further shrinkage of investment is therefore high.

\section{Conclusions}

Europe's tapestry of countries, history, structures of housing provision and policy frameworks present an interesting, if complex, laboratory in which to investigate housing policy. Only a taste of what that laboratory offers has been surveyed here but a number of conclusions stand out.

Despite the myriad of detailed policy and institutional differences between countries what is most notable from Europe's recent housing history is the importance of general living standards. People on average in richer countries are better housed than in poorer ones. Furthermore, experience shows that the worst that can happen to housing provision is the onset of major financial and macroeconomic instability. So, growth, stability and well-functioning markets are catchwords for the principles of effective housing provision.

None of the above factors directly relate to what is generally termed housing policy. This observation should help temper views of the effectiveness of strongly interventionist housing policies. Nonetheless, housing issues are vital in wider policy debates. Recent history shows that housing provides key elements for policies that promote steady economic growth and the creation of stable financial markets (IMF, 2015); while neglect of key housing outcomes, as in discussions over Basle III, impose unnecessary long-term costs. 
Another noticeable feature of Europe's various housing systems is the strongly ingrained idea that governments can and should help with particular groups' housing circumstances. This is done by tweaking the rules and other institional arrangements in their favour through tax breaks, subsidies, the ring-fencing land and homes, or by controlling prices/rents. On a partial basis, justification may always seem sound but, unfortunately, what are generally being interfered with are interlinked systems of competition over the relatively small areas of land that constitute any countries' dense-urban areas. Moreover, there are spillover effects to other activities, such as labour markets.

So, a housing-related privilege to one is often a loss to another. This might encourage further state interventions in attempts to offset some of those losses and so it goes on over time, with layers easier to add than remove. Moreover, once in place interventions are hard to reverse and housing systems and stocks become ossified. Privileges can also threaten stability by encouraging specific behaviours, such as loading up on debt.

Many policies persist through inertia or political support by interest groups rather than for genuine welfare or efficiency concerns. So, policy debate has to recognise insiders and outsiders as well as winners and losers. Yet it is difficult for politicians to look beyond the interests of specific spatially distributed groups whose voting is central to their own existence while there is little pay-off for them in policies that only bear fruit in the long-term.

Further problems arise because most interventions are demand-side ones into land and housing markets. In aggregate, such boosts to urban demand invariably push up prices for everyone. Hardly any interventions aim to diminish housing demand.

Fortunately, supply-side changes can alter housing circumstances over the long-term by creating extra housing. For real impact, their effect has to be a net one rather than end up replacing one type of home with another, while expanding aggregate urban demand, as can occur with public/affordable building programmes.

Supply-side policies may relate to the existing stock by creating better situations where maintenance and improvement are feasible up to economically viable levels or by encouraging better stock use through improving matching and transactions costs. Of course, new building is the most effective but European governments have shown themselves reluctant to facilitate the large increases in supply that are required in many major city regions. Infrastructure is costly - especially at times of 
fiscal austerity - and suburbanites value current densities over new build and vote that way. 


\section{Bibliography}

Alesina, A., Glaeser, E. and Sacerdote, R. (2001) 'Why doesn't the United States have a European-style welfare state?', Brookings Papers in Economic Activity, 2, 182-277.

Andrews, D., Caldera Sanchez, A. and Johansson, A. (2011) Housing markets and structural policies in OECD countries, Economics WP836, OECD, Paris.

Andritzky, J.R. (2014) 'Resolving mortgage distress: time to modify?', IMF Working Paper WP/14/226.

Arnott, Richard (1995) Time for Revisionism on Rent Control? The Journal of Economic Perspectives 9(1): 99-120.

Ball, M. (2011) 'UK planning controls and the market responsiveness of housing supply', Urban Studies, 48(2), 349-362, February, 2011.

Ball, M. (2012) RICS Review of European Housing Markets, RICS, London.

Ball, M. and Morrison, T. (2000) "Housing investment fluctuations: an international comparison", Housing, Theory and Society, 2000, 17.1, 3-13.

Bank of Spain (2015) Financial Stability Report, 05/2015.

Barras, R. (2009) Building cycles. Growth and instability. Wiley-Blackwell, Chichester.

BIS (2015) Residential property price statistics, Bank for International Settlements, Geneva.

Birch, J. (2014) 'Impact of Help to Buy revealed', Inside Housing, April.

Braga, M. and Palvarini, P. (2013) Social housing in the EU, Directorate-General for Internal Policies, European Parliament, Strasbourg.

Case, K. and Shiller, R.J. (2003) 'Is There a Bubble in the Housing Market?', Brookings Papers on Economic Activity No. 2

Chen, S., Kim, M., Otte, M., Wiseman, K. and Zdzienicka, A. (2015) 'Private sector deleveraging and growth following busts', IMF Working Paper WP/15/35.

CBol (2015) Residential mortgage arrears and repossessions statistics, Statistical Release, March, Central Bank of Ireland, Dublin.

CECODHAS (2012) 2012 Housing Europe Review. The nuts and bolts of European social housing systems, CECODHAS, Brussels. 
Chatham House (2015) The welfare state in Europe. Visions of reform, European Programme Research Paper, Chatham House, London.

Cheshire, P. (2007) Segregated neighbourhoods and mixed communities. A critical analysis, Joseph Rowntree Foundation, York.

DCLG (2015) Land-use Statistics, DLCG, London.

De Boer, R. and Bitetti, R. (2014) A Revival of the Private Rental Sector of the Housing Market? Lessons from Germany, Finland, the Czech Republic and the Netherlands, OECD Economics WP 1170.

Dustmann, C. and Frattini, T. (2014) 'The Fiscal Effects of Immigration to the UK', The Economic Journal, 124: 593-643.

Early, F. (2004) 'What explains the differences in homeownership rates in Europe?' Housing Finance International, Sept., 25-30.

Eurostat (2014a) 'Population statistics at the regional level', Eurostat Statistics Explained, Brussels.

Eurostat (2014b) 'Housing statistics', Eurostat Statistics Explained, Brussels.

Frontier Economics (2014) Assessing the social and economic impact of affordable housing investment, London.

Garner, S. and Bhattacharyya, G. (2011) Poverty, ethnicity and place, Joseph Rowntree Foundation, York.

Greenhaugh, S. and Moss, J. (2009) Principles of social housing reform, Localis, London. Hemerijck, A. (2012) Changing Welfare States, Oxford University Press, Oxford.

Hills, J. (2007) Ends and means: the future roles of social housing in England, CASE, London School of Economics, London.

Griggs, J. and Kemp, P. (2012) 'Housing allowances as income support: comparing European welfare regimes', International Journal of Housing Policy, 12:4, 391-412.

Housing and Communities Agency (2012) Understanding Unit Costs of Housing Providers Regression Analysis Summary Report, Housing and Communities Agency.

IMF (2014) World Economic Outlook, Spring 2014.

IMF (2015) Housing Recoveries: Cluster Report On Denmark, Ireland, Kingdom Of The Netherlands-The Netherlands, And Spain IMF Multi-Country Report 15/1. 
Lux, M. and Sunega, P. (2014) 'Public housing in the post-same states of Central and Eastern Europe: decline and open future', Housing Studies,

Niemietz, K. (2012) Abundance of land, shortage of housing, Institute of Economic Affairs, London.

Norris, M. and Coates, D. (2012) 'How housing killed the Celtic Tiger: Anatomy and consequences of Ireland's housing boom and bust', Journal of Housing and the Built Environment, 29.2, 299-315.

Norris, M. and Winston, N. (2012) 'Home ownership, housing regimes and income inequalities in Western Europe', International Journal of Social Welfare, 21, 127-138.

Mian, A. and Sufi, A. (2014) House of Debt, University of Chicago Press, Chicago.

Milne, R. (2014) 'Central banks: Stockholm syndrome', Financial Times, 19.11.14.

Morris, J., Kovacs, B. and Harboe, I. (2014) ' "Welfare States" and social policies in Eastern Europe and the former USSR: where informality fits in?', Journal of Contemporary European Studies, 22.2, 184-194.

O'Sullivan, E. and De Decker, P. (2007) 'Regulating the private housing market in Europe', European Journal of Homelessness, 1, 95-117.

Pawson, H., Lawson, J. and Milligan, V. (2011) Social housing strategies, financing mechanisms and outcomes: an international review and update of key post-2007 policy developments, City Futures, University of New South Wales, Sydney.

Peri, G. (2013) 'The Economic Benefits of Immigration', Berkeley Review of Latin American Studies, Fall.

Phillips, D. (2013) Government spending on benefits and state pensions in Scotland: current patterns and future issues, BN139, Institute for Fiscal Studies, London.

Rhodes, M. and Mullins, D. (2009) 'Market concepts, coordination mechanisms and new actors in social housing', International Journal of Housing Policy, 9.2.

Scanlon, K. and Elsinga, M. (2013) Towards a sustainable private rented sector: The lessons form other countries, London School of Economics, London.

Thorhallsson, B. and Kirby, P. (2011) Financial crises in Iceland and Ireland: Does EU and Euro membership matter? Centre for Small State Studies, University of Iceland, Reykjavik.

UEPC (2013) European Union state aid rules remain necessary for tackling unfair competition on the housing markets, Brussels. 
Whitehead and Scanlon (2007) Social housing in Europe, London School of Economics, London. 